\title{
Diseases and Insect Pests associated with Cashew (Anacardium occidentale L.) Orchards in Ghana
}

\author{
A. Muntala, S. Kwadwo Gyasi, P. Mawuenyegan Norshie, S. Larbi-Koranteng, \\ F. Kwekucher Ackah, D. Afreh Ntiamoah, and M. Atef Mohamed
}

\section{ABSTRACT}

Cashew (Anacardium occidentale L.), a recently recognized cash crop in Ghana, is an economically export oriented crop that plays a helping role in the Ghanaian economy in diverse ways. Owing to its importance, surveys were conducted in some major cashew producing communities in Dormaa and Berekum West District of the Bono region to assess the problems of insect pests and diseases associated with this economic tree across the study area. Diseased samples showing varying degrees of symptoms were taken for isolation and identification using morphological method. Insect pests were also assessed and identified. The results showed Colletotrichum gloeosporioides species complex to be associated with anthracnose, leaf lesions or spots, gummosis of twigs and stems and regressive die-back; Lasiodiplodia theobromae was found to cause stem and twig gummosis, blight, die-back of twigs and inflorescence; Pestalotia sp. was associated with Pestalotia leaf spot. Others, such as Penicillium sp., powdery mildew, Curvularia lunata, Cephaleuros sp. (red rust- algal leaf spot), mushroom and lichens were also found to be associated with the cashew orchards in the study area. Anthracnose, gummosis, algal leaf, and stem spots (red rust) and cashew kernel infection by Curvularia lunata constituted the major diseases of cashew in ascending order in the study area. The insect pests identified included Oecophylla smaragdina, Anoplocne miscurvipeson, Pseudotheraptus devastans, Pachnoda cordata, Pachnoda marginata, Helopeltis bug, Helopeltis schoutedeni, Planococcus sp., Lamida moncusalis, Odontotermes sp., Aphis sp., Analeptes trifasciata. Some unidentified pathogens, pests and other abnormalities were also observed.

Keywords: Anacardium occidentale, Bono region, Cashew orchards, Diseases, Insect pests.

Submitted : August 15, 2021

Published : September 05, 2021

ISSN: $2684-1827$

DOI: 10.24018 / ejfood.2021.3.5.357

\section{A. Muntala*}

University of Energy and Natural Resources, Department of Horticulture and Crop Production, Bono Region, Ghana.

(e-mail: muntala.abdulai@uenr.edu.gh) S. Kwadwo Gyasi

University of Energy and Natural Resources, Department of Horticulture and Crop Production, Bono Region, Ghana.

(e-mail: kwadwo.santo@uenr.edu.gh)

P. Mawuenyegan Norshie

University of Energy and Natural Resources, Department of Horticulture and Crop Production, Bono Region, Ghana.

(e-mail: patrick.norshie@uenr.edu.gh) S. Larbi-Koranteng

Department of crop and soil sciences, College of Agriculture Education, University of Education, Winneba (UEW), Ghana.

(e-mail: larbikoranteng @ yahoo.com) F. Kwekucher Ackah

University of Cape Coast, Department of Crop Science, Cape Coast, Central Region-Ghana West Africa.

(e-mail: frank.ackah@ucc.edu.gh)

D. Afreh Ntiamoah

University of Energy and Natural Resources, Department of Horticulture and Crop Production, Bono RegionGhana.

(e-mail: daniel.afreh ${ }^{@}$ uenr.edu.gh)

M. Atef Mohamed

Fayoum University, Faculty of Agriculture, Department of Botany, Egypt.

(e-mail: amm12@fayoum.edu.eg)

*Corresponding Author

\section{INTRODUCTION}

Cashew (Anacardium occidentale L.), which belongs to the family Anacardiaceae is a perennial, drought-resistant cash crop cultivated by millions of people across the world. It is believed to have been originated from Central Brazil in the Southern America and was introduced into Africa by the
Portuguese in the $16^{\text {th }}$ century [1]-[3]. The tree crop is also found to be an indigenous species in the savanna ecology of the Guyanas, Colombia and Venezuela as well as a dominant species in the savanna-like vegetation (Cerrados) of the Amazonian and central areas of Brazil [1].

The tree crop is mostly cultivated in the areas lying between $15^{\circ}$ North Pole and South Pole of the equator [4], 
where ecological conditions are known to have high to optimal temperatures for cashew seed germination [5], unpredictable rainfall, poor soil nutrition and significant amount of soil salinity [6]. In Ghana, the crop is cultivated in the Bono, Bono East, Ahafo, Northern, Upper West, Upper East, Greater Accra, and Central Regions. The cultivation of this economic tree all over the world is threatened by a number of factors, the most important pathological problems being pests and diseases. Pests and diseases have been found to limit the yield output of cashew to a red flag level if timely interventions are not carried out. The cashew tree is known to be infected by different pathogens leading to numerous diseases that include anthracnose, leaf spots, gummosis and die-back linked to Colletotrichum gloeosporioides species complex and other pathogens [7], [8]. Nari [9] reported anthracnose of the leaves, gummosis of stem and twigs and cashew fruit rot as the most important diseases, which cause substantial yield losses in cashew production. Of the over 12 diseases of cashew caused by fungi, anthracnose leaf spot and fruit rot caused by Colletotrichum gloeosporioides Penz. \& Sacc, and gummosis of stem and twigs induced by Lasiodiplodia theobromae (Pat.) are considered the most important limiting biological agents in cashew producing regions of the world [10], [11].

Other diseases and pathogens that are known to infect cashew include: powdery mildew (Oidium anacardii) [12], [10], leaf and nut blight' by Cryptosporiopsis spp. [13], [14], Fusarium wilt disease [15], Pestalotia leaf spot caused by Pestalotia spp. [16], [17], red rust algal disease caused by Cephaleuros virescens [18], black mold (Pilgeriella anacardii) [19], [10], Angular leaf spot caused by Septoria anacardii [20], Phyllosticta brasiliensis, Corynespora hansfordii, Phomopsis anacardii, Cladosporium sp., Capnodium sp., Curvularia lunata and Microxyphium sp. [21]-[24], [16]. A cashew tree has been reported to be infested with a number of important insect pests at every stage of their growth [25], [26]. In a survey conducted in ten (10) major cashews growing Districts of Eastern, Upper West, Brong Ahafo and Northern regions of Ghana, [27], reported about 170 different insect species in various cashew farms visited. Some of the important insect pests of cashew plant include tea mosquito bug (Helopeltis schoutedeni, H. anacardii, $H$. antonii, $H$. theivora and $H$. bradyi), Pseudotheraptus wayi [28]-[31]. In India, insects like cashew stem and root borers (Plocaederus ferrugineus, P. obesus Gahan and Batocera rufomaculata), apple and nut borer (Thylocoptila panrosema), thrips (flower thrips: Rhynchothrips raoensis; Foliage thrips: Selenothrips rubrocinctus), mealy bug (Ferrisia virgate), leaf miner (Acrocercops syngramma) and leaf and blossom webber (Lamida moncusalis) have been reported as serious insect pests of cashew [31]. Other minor insects are Mecocorynus loripes, Pseudococcus longispinus, Analeptes trifasciata and crazy ants, among others [32], [33]. The objective of this study was, therefore, to document and report the problems of diseases and insect pests that are associated with the cashew orchards in the study area.

\section{MATERIALS AND METHODS}

\section{A. Survey and Collection of Infected Cashew Samples}

Owing to the complaints from cashew farmers in and around Dormaa East District, Dormaa Central Municipality as well as Berekum west District in 2019, about the problems of pests and diseases in their orchards, a survey was initiated in 2019, and 2020 in fifty (50) cashew orchards in these communities. Five (5) orchards were randomly selected from each of the seven localities in the Dormaa Central Municipality and these areas included: Kyeremansu and Tonasuano to the east of Dormaa township, Agyemankrom, Antwirifo, Suromani, Atesikrom and Badukrom to the west of the Municipal capital. Ten (10) orchards, 5 each from Amomaso and Nseseresu in the Dormaa East District and five (5) orchards from Nsapor in the Berekum West District of Bono Region of Ghana as shown in Fig. 1. Samples of the diseased cashew trees such as leaves, trunk bark, inflorescence, twigs and nuts showing varying degrees of suspected symptoms were collected for critical evaluation and isolation of the putative pathogen. The samples were collected into brown envelopes, sealed, and transported to the Laboratory of the University of Energy and Natural Resources, Sunyani for isolation.

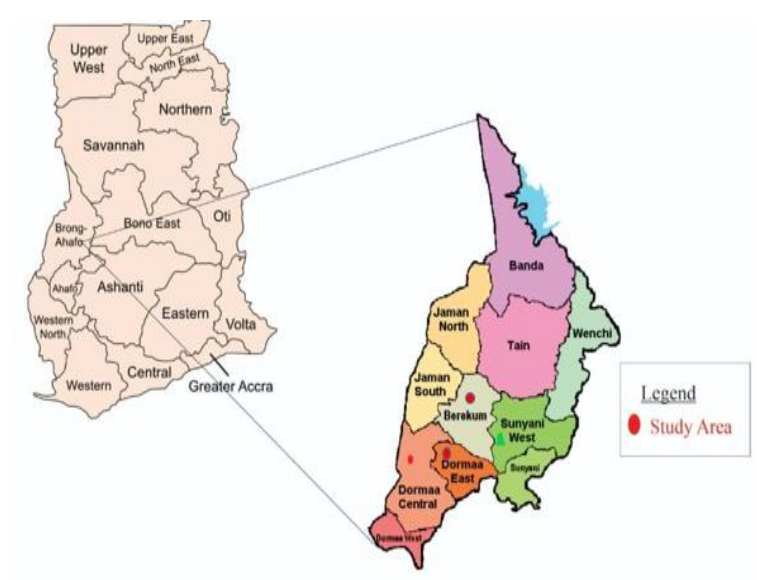

Fig. 1. Map of Ghana showing study area.

\section{B. Pathogen Isolation}

The putative pathogen was isolated from the diseased samples under aseptic conditions in Laminar flow using flamed forceps and a knife. The diseased portion $(3 \mathrm{~mm})$ was carefully cut together with the adjacent healthy portion. The cut tissues were sterilized in $70 \%$ ethanol for a minute, then transferred into three exchanges of sterilized double distilled water to remove the traces of ethanol. With the aid of the flamed forceps, the washed sterilized tissues were picked and blotted dry on Whatman's paper for few minutes, after which they were placed on the prepared Potato Dextrose Agar (PDA), which was autoclaved at $121{ }^{\circ} \mathrm{C}$ for 15 minutes. The tissues were placed at equidistance and replicated three times in each and in separate Petri dishes, incubated at $28{ }^{\circ} \mathrm{C}$ for 3 to 7 days for the observation of the fungi growth. Hypha tip sub culture technique was used to obtain the pure cultures, which were stored at $-20{ }^{\circ} \mathrm{C}$ and used for pathogen identification and pathogenicity.

\section{Pathogens and Insect Pests' Identification}

Morphological evaluation and identification of the putative 
pathogens causing number of diseases on the cashew trees were done using morphological characters like colony colour and texture, hyphae type, sporulation, conidial size, and shape according to [34]-[37] protocols, and detailed description from other literature. Wet mount of the pure pathogen was prepared using sterilized distilled water with the aid of pipette. About $2 \mu \mathrm{m}$ of the spore-water suspension was dispensed on the slide, covered with the slide slip and viewed under compound light microscope (Olympus CX23, $40 \mathrm{X} / 0.25 \infty /-/ \mathrm{FN} 20)$ at $(40 \mathrm{X})$. The insect pests were identified with the help of an Entomologist from the Savannah Agriculture Research Institute (SARI)- Ghana. Bacterial and viral diseases as well as nematode damages were not assessed during the study.

\section{Pathogenicity Test}

The inoculation of the pure culture of the pathogen was done on the two-month cashew seedlings. The spores were harvested by flooding the Petri dishes with autoclaved sterile distilled water. The suspensions were collected in the flat bottom flask, from which aliquots were used to make the necessary measurements and adjustment to the appropriate concentration of $1 \times 10^{6}$ conidial suspensions/ mL. The seedlings were inoculated with the suspension after slightly wounding the plants and misting them. The setup was allowed to stand overnight in enclosed polyethylene sheets to provide the necessary humidity for fungi growth and development. The sheets were removed the previous day and the plants closely monitored for disease progression and development. Those plants used as controls were only sprayed with water after wounding.

\section{RESULTS}

\section{A. Diseases, Pathogens and Pest Profiles of Cashew Trees}

A number of diseases and pests were observed and recorded during the survey in selected cashew orchards in the study area. Diseases such as anthracnose, gummosis, dieback, Pestalotia leaf spot, algal leaf and stem spots (red rust), powdery mildew, Penicillium and Curvularia infection, mushroom and lichens growth as well as insect pests such as Oecophylla smaragdina (weaver ant), Anoplocne miscurvipeson, Pseudotheraptus devastans, Pachnoda cordata, Pachnoda marginata, Helopeltis bug, Helopeltis schoutedeni, mealybugs (Planococcus sp.), leaf and blossom webber Lamida (Macalla) moncusalis, Termites (Odontotermes sp.), aphids (Aphis spp), leaf miner and cashew girdler beetle (Analeptes trifasciata) were all observed on the cashew trees in the study area. Anthracnose, gummosis and algal leaf and stem spots (red rust) and cashew kernel infection by Curvularia lunata constituted the major diseases of cashew in ascending order in the study area.

Detailed profiles of the diseases and associated pathogens are discussed below: Cashew anthracnose (necrotic watersoaked spots on leaves, flowers and apples that later become orange-brown or red, wrinkled and dry up, sometimes with shoot hole appearance in the leaves, small dark lesions on the inflorescence, panicle and lateral branches, that later dry up and fall, infected immature fruit becomes black, dry and fall off prematurely, mature fruits with round or irregular sunken spots as well as mummified seeds), gummosis and progressive die-back caused by:

\section{B. Colletotrichum gloeosporiodes}

If Colletotrichum gloeosporiodes were observed across all the study areas (Fig. 2). All the isolates were identified on the basis of mycelium and conidial morphology, size and colour using standard identification protocols [34]-[37]. The $C$. gloeosporiodes morphologically produced hyaline branched and septate mycelium on the PDA (Fig. 3a-c) and straight or slightly curved, hyaline, cylindrical conidia with round or obtuse edges. Variable conidia ranging between 9-15 $\mu \mathrm{m}$ up to $20 \mu \mathrm{m}$ in length and diameter of 3-6 $\mu \mathrm{m}$ were observed (Fig. 3d).

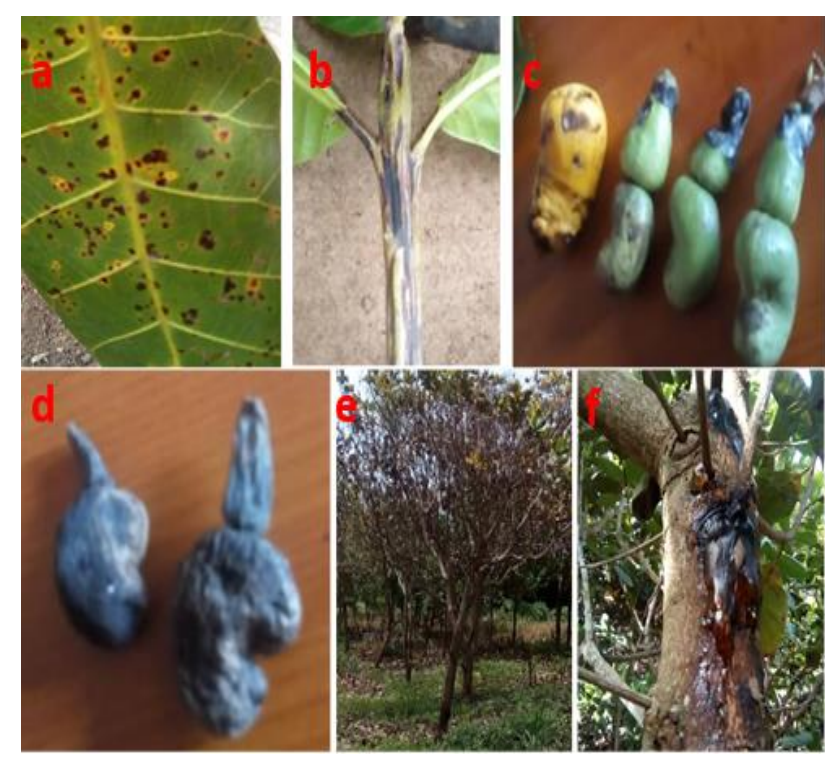

Fig. 2. A-D Anthracnose, (E) die-back, (F) gummosis diseases caused by Colletotrichum gloeosporiodes.

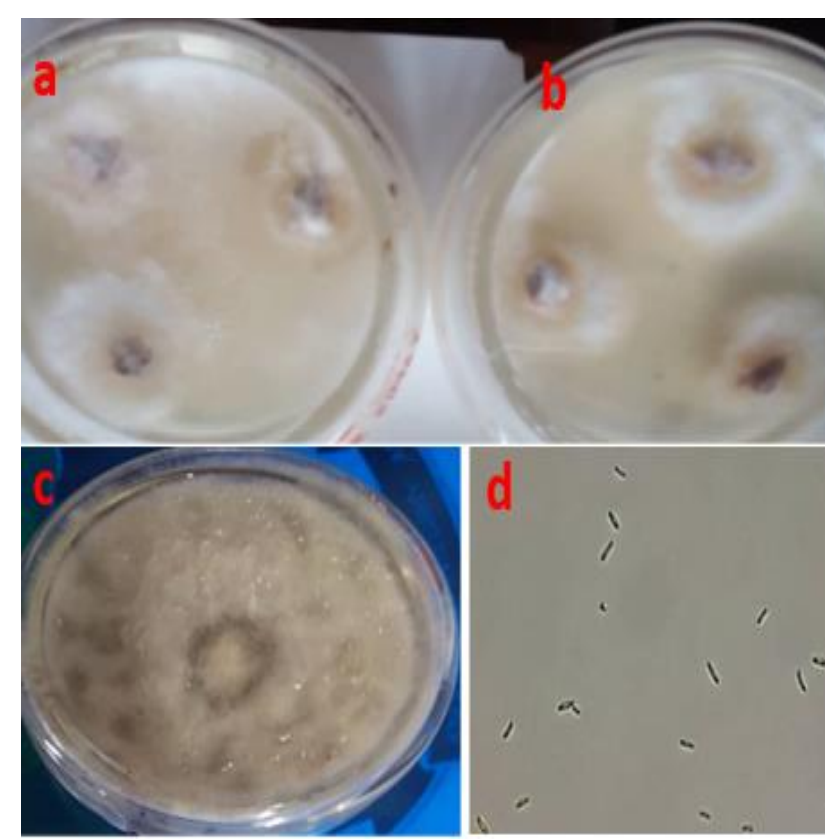

Fig. 3. (A- C) Colletotrichum gloeosporiodes mycelia (D) conidia (40X) isolated from cashew tissues.

\section{Cashew Gummosis}

Cashew gummosis partly caused by Lasiodiplodia theobromae (symptoms on the trunk, twigs and branches are 
characterized by dark brown gum exudates which becomes black after drying, inner portion of the trunk or branch when split longitudinally showed some reddish-brown necrotic tissues, bleeding cankers etc.) (Fig. 4a, b, c). The conidia of the fungus were initially hyaline and aseptate but later becomes dark brown as it matures with single septation. It is generally rounded at the tip and truncate at the base and has irregular longitudinal striations (Fig. 4d).
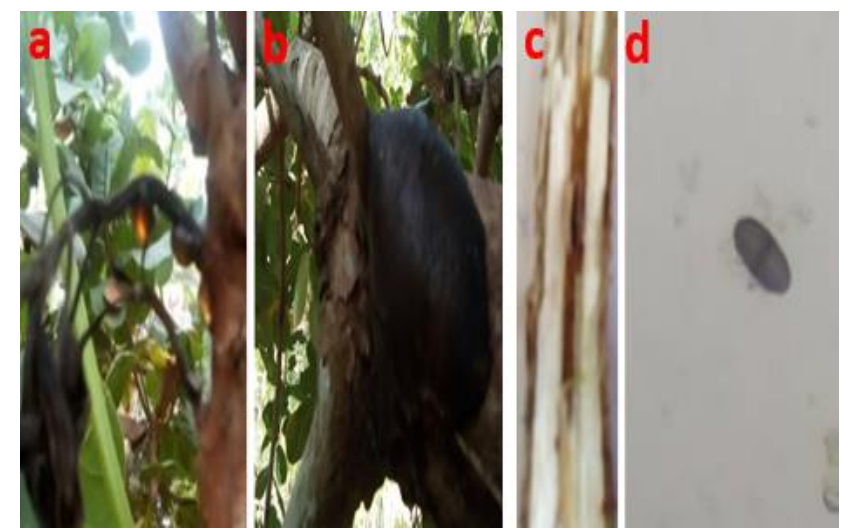

Fig. 4. (A) brown gummy exudate (B) black dried exudate $(\mathrm{C})$ reddish brown inner necrotic tissues (D) mature septate conidium (40X) of Lasiodiplodia theobromae.

\section{Pestalotia Leaf Spot}

Pestalotia leaf spot caused by Pestalotia sp. is characterized by upper reddish brown angular or irregular lesion and pale grey to whitish at the abaxial part of the leaf (Fig. 5a). The typical cultural and morphological characteristics of the isolated pathogen as grown on the PDA and observed under the microscope is shown. The isolates showed grayish to white colonies which later became dark with maturity (Fig. 5b).
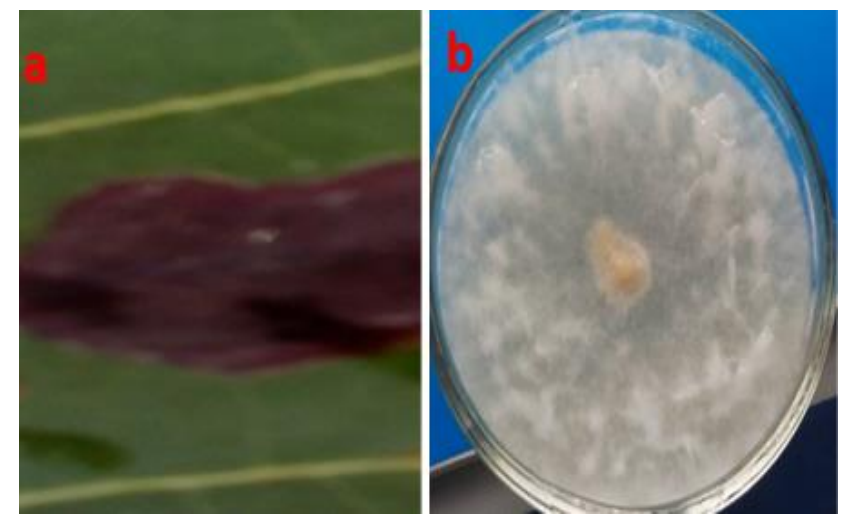

Fig. 5. (A) Pestalotia leaf spot on cashew leaf (B) grayish to white mycelia sub-culture.

\section{E. Powdery Mildew}

Powdery mildew caused by Oidium sp. and other fungal species in the order Erysiphales, mostly occur on the leaves, branches, fruits, and inflorescence. They are characterized by whitish powdery spots or colonies of the fungus on the infected tissues (Fig. 6). The disease was observed more on the leaves than found on the apples and nuts.

\section{F. Algal Leaf Spot}

Algal leaf spots (Cephaleuros sp.) symptoms observed on the leaves were characterized by circular rust-coloured or burnt-orange to brown colour on the adaxial part of the leaves often called red rust (Fig. 7). The spots are slightly raised and filamentous in nature with fuzzy topographies.

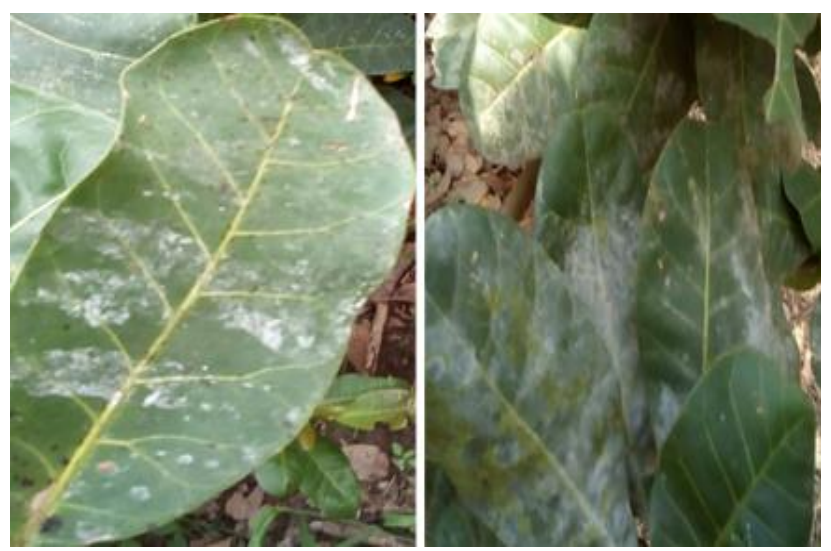

Fig. 6. Powdery mildew colonies on cashew leaves.

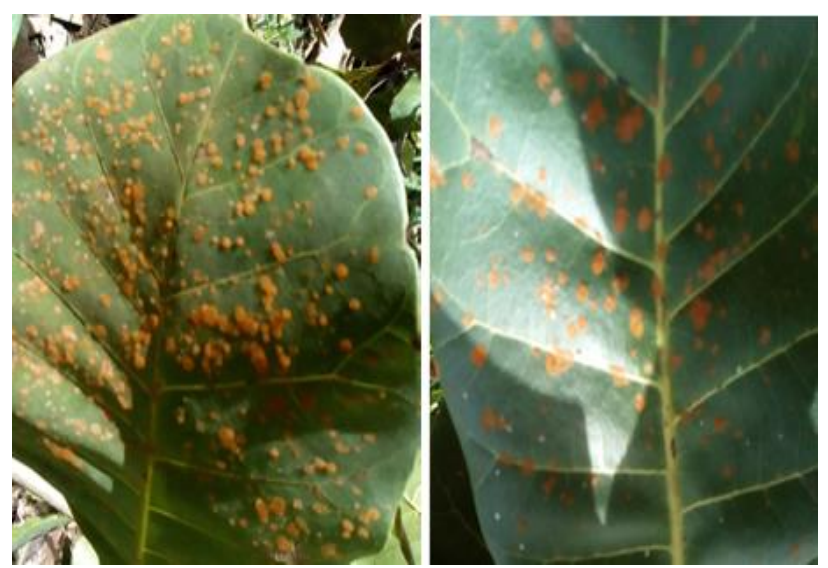

Fig. 7. Algal leaf spot (red rust) on the cashew leaves.

\section{G. Algal Stem Spot}

Algal stem spot (Cephaleuros sp.) symptoms were observed on the cashew stems in all the orchards visited, especially the old ones. The symptoms are characterized by circular or irregular green-gray spots or compact colonies as shown on the stem. Under severe conditions, the entire stem or bark is covered with the colonies of the fungi (Fig. 8).
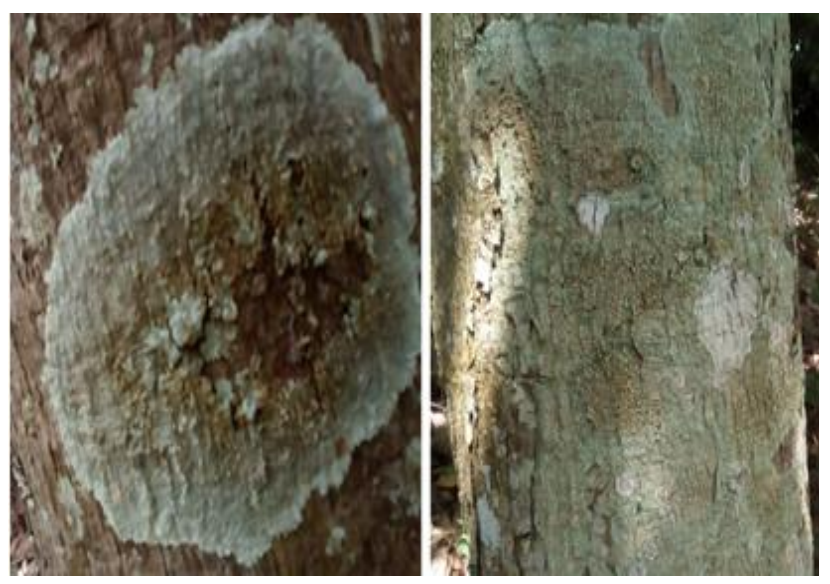

Fig. 8. Algal stem spot on the cashew stem.

\section{H. Lichen Spot}

A $\mathrm{n}$ Lichen spot (association between fungi and algae) were observed on the stems of the cashew trees. The symptoms observed are characterized by circular or irregular low, flat, crusty, greenish spots or colonies on the stem. The 
spots are loosely attached to the bark surfaces and spread around it, but do not penetrate the bark tissue (Fig. 9).
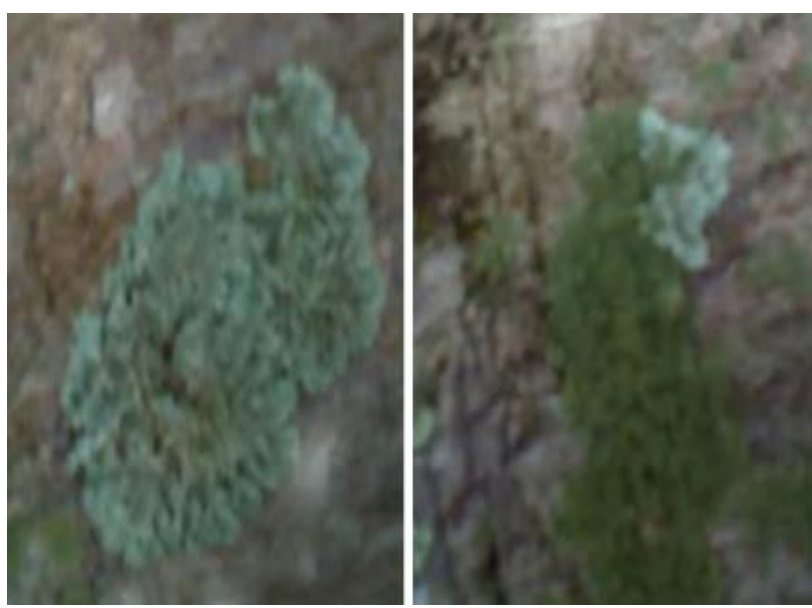

Fig. 9. Lichen stem spots on the cashew stem.

\section{Mushroom (Fungi) Fruiting Bodies}

Mushroom (Fungi) fruiting bodies called conks were found growing on the pruned scars of the cashew branches in some visited orchards in the study area. Though some of these pathogens are opportunistic fungi, most are capable of destroying the trees by utilizing the cellulose, the hemicellulouse, and the lignin tissues of the tree and thereby compromising the tree defense systems. The fruiting bodies were found to cause decay of the cashew branches as observed in this study (Fig. 10).

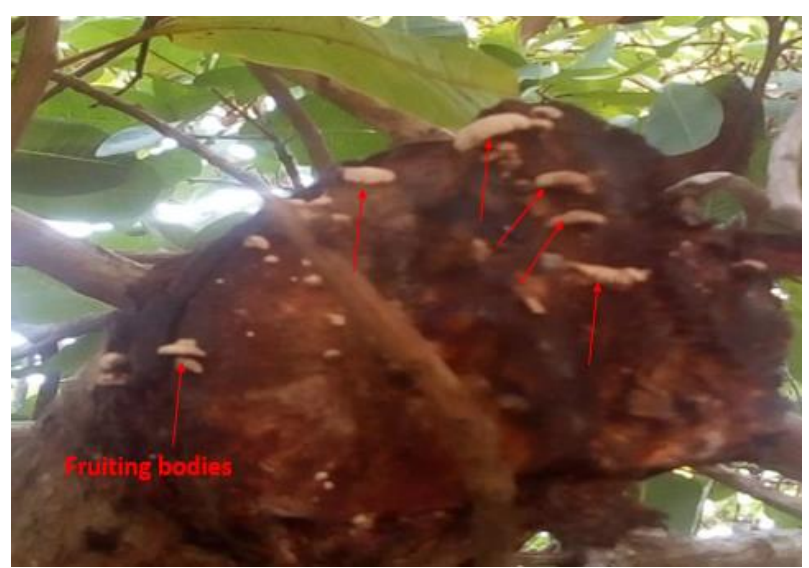

Fig. 10. Mushroom fruiting bodies causing branch rot of cashew tree after pruning.

Other pathogens such as Penicillium spp., Curvularia lunata as well as insect damages were also found to be associated with leaves, twigs, branches, and dead nuts.

\section{J. Penicillium spp.}

Penicillium spp. were isolated from the infected unripe and ripped seeds or nuts. The fungus growth was found to be a major problem associated with fresh unripe cashew nuts in the various orchards and continue to pose a threat during postharvest. The fungus is characterized by fast growing, smooth to powdery green or grey-green or white colonies as observed on the fresh unripe nut and ripped apple as well as on PDA in Petri dishes (Fig. 11). The mycelium is copiously branched with hyphae that are septate in nature.

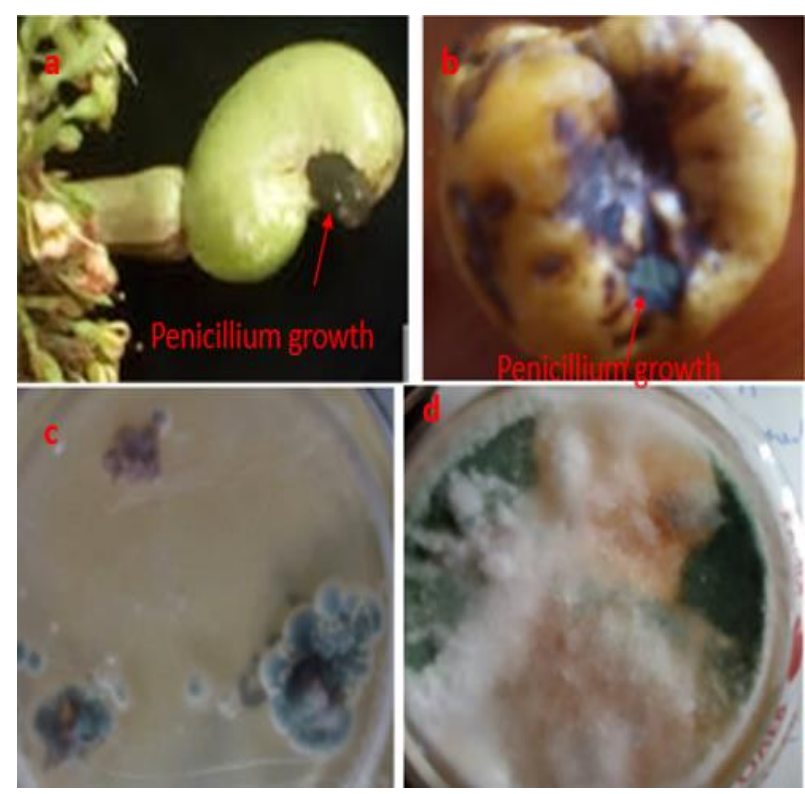

Fig. 11. Cultural characteristics of Penicillium spp. growth on (A) fresh nut (B) ripped nut (C-D) on PDA.

\section{K. Curvularia lunata}

Curvularia lunata isolated from the cashew trees produced initially white to pinkish grey woolly colonies on top, which later became olive brown or black with time. Upside down, the colony looks dark brown to black in pigmentation. The fungus has proconidia that are pale brown in colour. The conidia are curved or lunate due to swelling of the central cell, transverse multiseptate ( 3 septa) and divided into four multiple cells (Fig. 12).
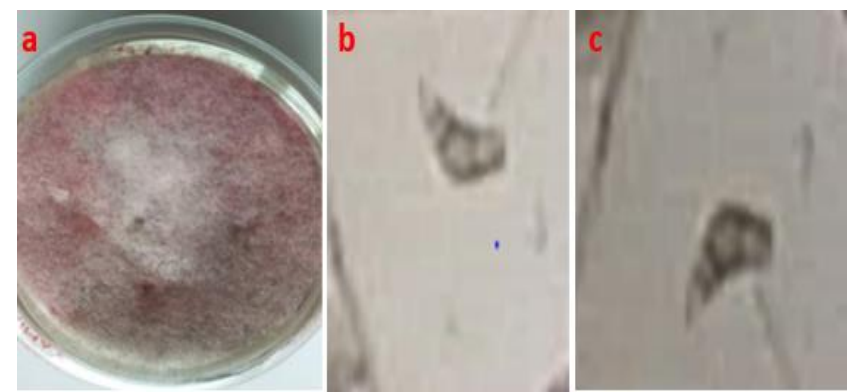

Fig.12. (A) fungus growth showing white to pinkish grey woolly mycelium (B-C) conidia of Curvularia lunata isolated from cashew kernel.

\section{Cashew Branch Girdle}

Cashew branch girdle caused by cashew girdler beetle (Analeptes trifasciata) was also observed. The beetle was found to girdle small branches of about 4-10 $\mathrm{mm}$ in diameter in a circular form around the branch, leaving a weak narrow central pith that finally breaks off with slight wind or mechanical shake up. Also shown is the Girdler beetle responsible for the damage (Fig. 13).

\section{Other Insect Pests}

Other insects identified included: Oecophylla smaragdina (weaver ant), Anoplocne miscurvipeson, Pseudotheraptus devastans, Pachnoda cordata, Pachnoda marginata, Helopeltis bug, Helopeltis schoutedeni, mealybugs (Planococcus sp.), leaf and blossom webber Lamida (Macalla) moncusalis, Termites (Odontotermes sp.), aphids (Aphis spp.) and leaf miner (Fig 14a- k). Some of the insect species have not been identified. 


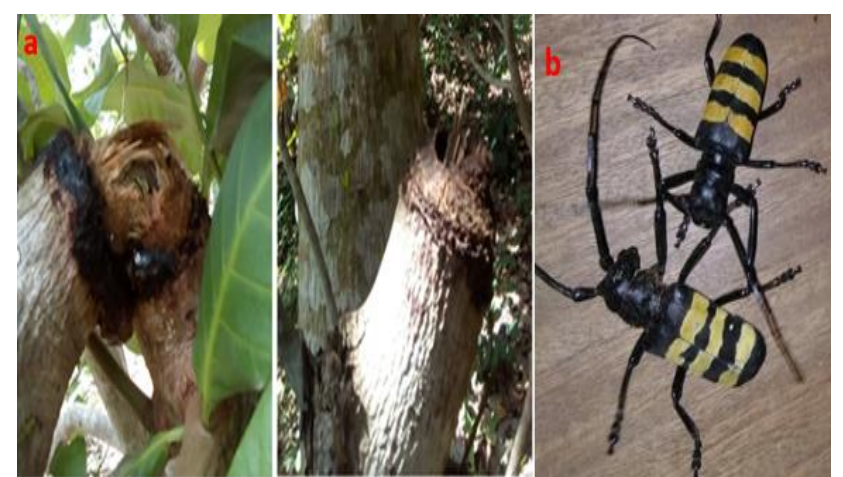

Fig. 13. (A) Girdled cashew branch tipped-off (B) Girdler beetle (Analeptes trifasciata).
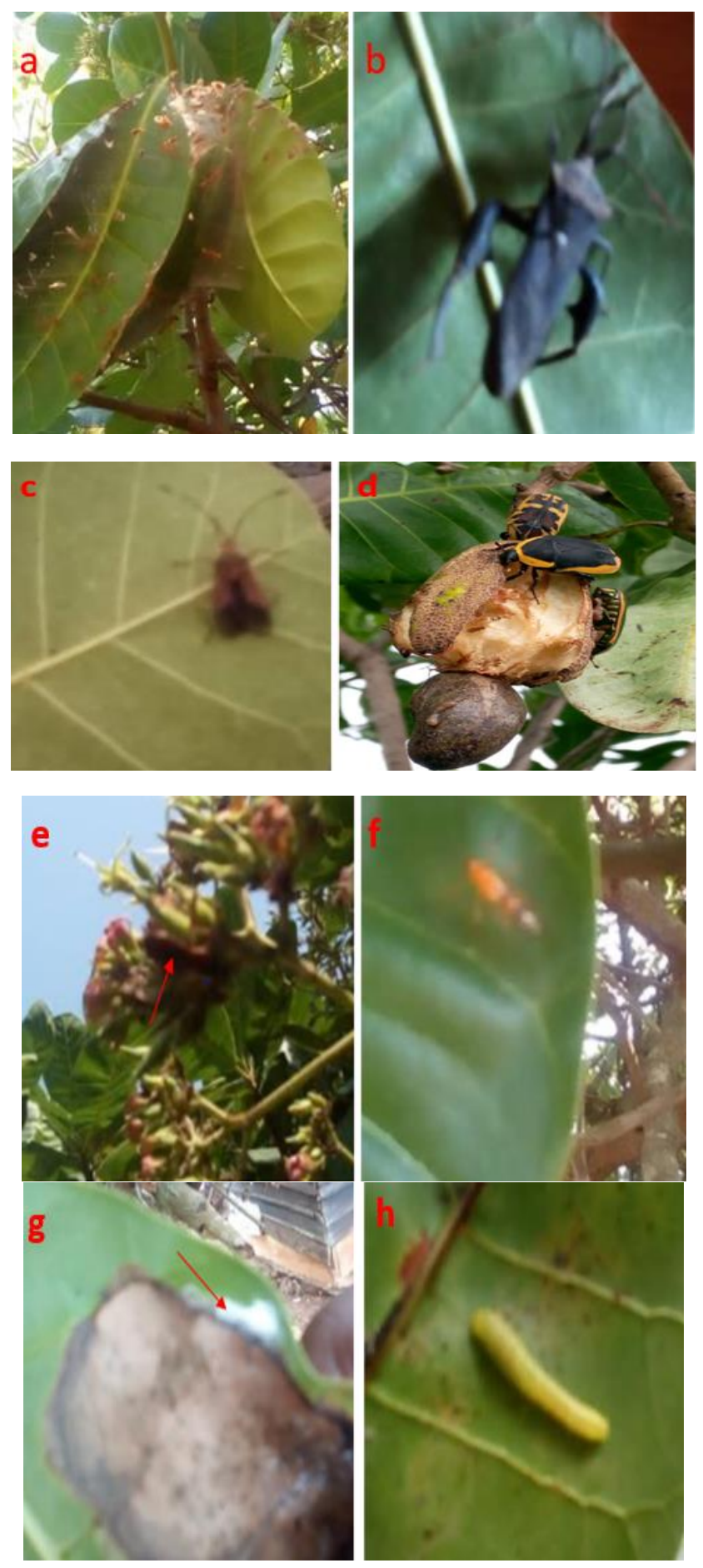
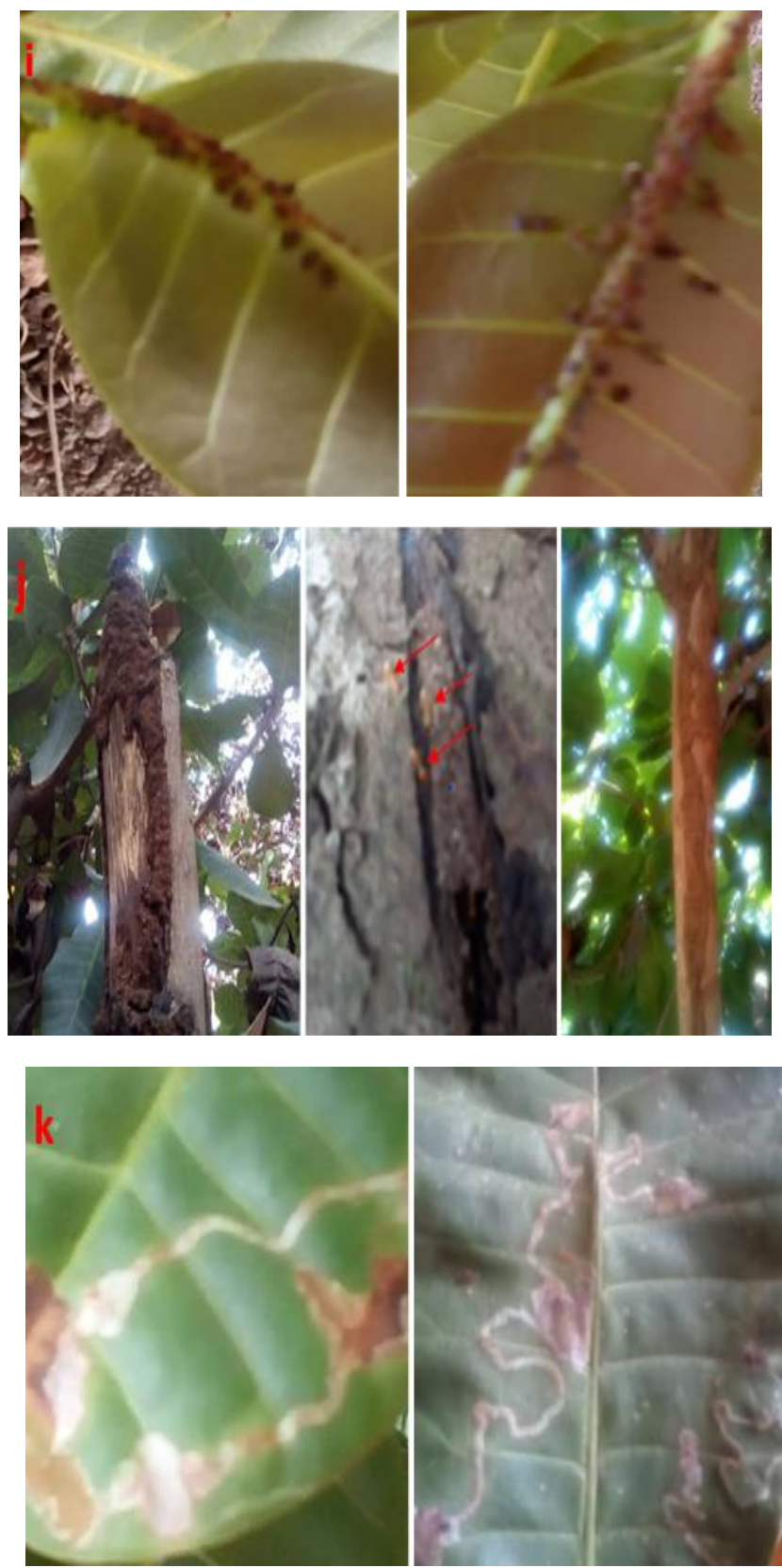

Fig. 14. (A) Oecophylla smaragdina (weaver ant nest) (B) Anoplocne miscurvipeson. (C) Pseudotheraptus devastans D) Pachnoda marginata,

Pachnoda cordata. (E) Helopeltis bug (F) Helopeltis schoutedeni.

(G) Mealybugs (Planococcus sp.) (H) Leaf and blossom webber Lamida moncusalis. (I) Aphids (Aphis spp) on cashew leaves. (J) Termites damage on cashew tree trunk. (K) Cashew leaf mining by leaf miner showing squiggly lines in the leaves.

\section{N. Pathogenicity}

The pathogenicity test using isolates of Colletotrichum gloeosporiodes proved positive. The pathogen was found to be pathogenic and induced varied symptoms on the inoculated cashew seedling as shown in Fig. 15. Pathogenicity using other isolated pathogens from the infected cashew trees could not proceed because of the poor sporulation of the fungi during culturing. The pathogen produced similar symptoms as observed in the field and was consistently re-isolated from the inoculated cashew seedlings, thereby confirming the Koch's Postulate. 


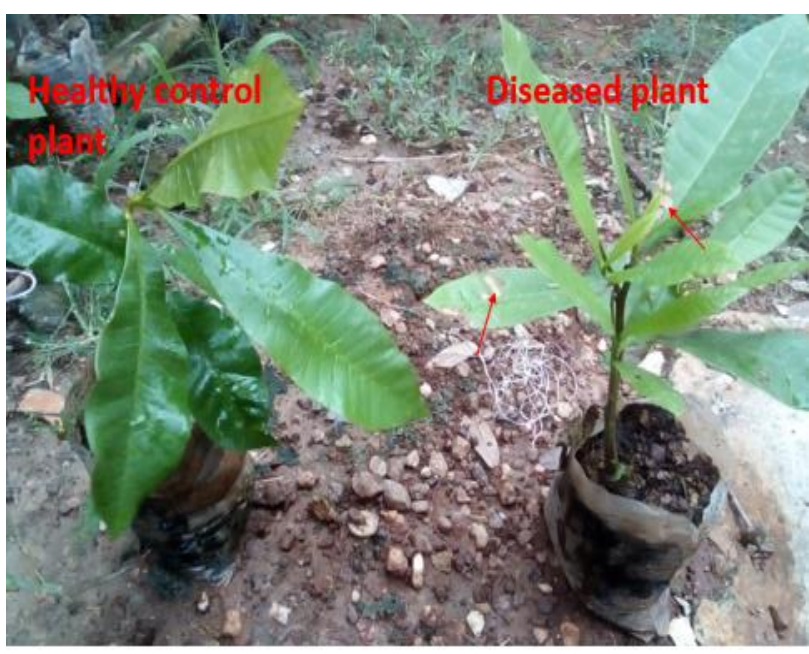

Fig. 15. Pathogenicity of Colletotrichum gloeosporiodes on cashew seedlings.

\section{DISCUSSION}

Cashew tree diseases and pest profiles were assessed in various communities in the Dormaa Central Municipality, Dormaa East and Berekum west Districts in the Bono Region of Ghana. Many studies have been done on cashew in Ghana, but there is very little published information regarding cashew diseases not only in the Bono region, but other major cashew growing regions of the country as well. During the survey, which was initiated due to the complaints from the cashew farmers, varied incidences of pests and diseases in the various orchards in the study areas were observed. The diseases and pests observed and documented included anthracnose, gummosis, die-back, Pestalotia leaf spot, algal leaf and stem spots (red rust), powdery mildew, Penicillium and Curvularia infections of the kernel, mushroom and lichens growth. Although some pathogens associated with the cashew were not identified, among all the diseases recorded, it was observed that anthracnose caused by Colletotrichum gloeosporioides constituted the highest of all, followed by gummosis caused by Lasiodiplodia theobromae, algal leaf and stem spots (red rust) caused by Cephaleuros virescens and cashew kernel infection by Curvularia lunata in order of importance. Pestalotia leaf spot was not widespread in the study area, it was spatially observed with low occurrence. The pathogen Colletotrichum gloeosporioides, which causes anthracnose disease of cashew is highly variable in terms of pathogenicity and morphology and infects not only cashew, but also other important tropical fruit crops as well [38], [39]. They infect all parts of cashew plants including leaves, inflorescences, fruits, and apples as well as twigs and produce varied symptoms like sunken, circular or irregular spots with mucilaginous mass spores during favourable environmental conditions [40].

In the eastern Africa country of Tanzania, diseases like powdery mildew, anthracnose, nut and leaf black rust as well as bacterial foliar diseases are considered the most important, and they have been reported to cause varying degrees of damage and yield losses (70 to $100 \%$ ) to cashew and its products [41], [42]. In order of importance, cashew powdery mildew caused by Oidium anacardii Noack, has been considered the most serious disease [43], [12], in 2003, followed by second most damaging disease 'cashew leaf and nut blight' established to be caused by Cryptosporiopsis spp. [44], [13], [14], and in 2012, Fusarium oxysporum causing Fusarium wilt disease has been reported as the third deadliest disease of cashew in Tanzania [15]. Yield losses of up to $100 \%$ has been proposed if not timely controlled [45]. Whilst in Tanzania powdery mildew has been considered the most dreadful disease, it has been reported as of less significance to cashew production in Brazil with a negligible threat to cashew output [19], [10]. In Brazil, like Ghana, anthracnose has been found to be the most serious disease of cashew [19], [46], [8]. Also, in Ghana, Muntala [8] reported gummosis and red rust in addition to anthracnose as the most important diseases associated with cashew orchards in the Bono region.

In Mozambique, Colletotrichum gloeosporioides has been reported to cause a serious anthracnose of cashew [47] and in Nigeria, Lasiodiplodia theobromae has been established to cause twig dieback and inflorescence blight of cashew and considered as the most limiting factor to cashew nut yield [48]. In the neighboring Burkina Faso, major diseases like anthracnose caused by Colletotrichum gloeosporioides; gummosis by Lasiodiplodia theobromae; Pestalotia leaf spot caused by Pestalotia heterocornis and bacterial leaf and nut spot caused by Xanthomonas citri pv. anacardii have been considered the most important diseases [17]. In Benin Republic, powdery mildew, anthracnose, Pestalotia leaf spot and algal leaf spot (red rust) have been recorded as a major threat to cashew production [18]. In a survey conducted in the various cashew orchards in Guinea-Bissau, as part of international project, "Cashew in West Africa, Monteiro [49], reported the presence of anthracnose and gummosis in various orchards in that region. All the above findings completely or partially agreed with the findings of this study.

The major problem observed on the cashew kernel in the various orchards across the study area was Penicillium growth, which recorded varied degrees of kernel rots and resulted in the reduction of the kernel quality. The Penicillium growth was more visible on the fresh cashew kernel at the early stage of fruit development as well as on ripped apple as observed during the survey. In India, Penicillium sp., Cladosporium sp., Fusarium sp., Rhizopus sp. and Aspergillus niger have been reported as the causal agents of kernel rot in mature and immature nuts [50]. In Brazil, Penicillium digitatum is blamed for a kernel rot in cashew plant [51]. Other fungi like Neurospora sp., A. flavus and Oedocephalum bergii have been detected in the kernel [52] as well, and in Nigeria, Fusarium spp., Aspergillus sp., Gliocladium spp. and Rhizopus nigricans have been reported by [53] as responsible for causing kernel rot.

Management and control of these pathogens causing diseases in the various cashew orchards are paramount to increase cashew productivity. Number of control methods ranging from cultural, biological, and chemical methods have been proposed. Cashew anthracnose can be controlled culturally (e.g., by cutting down and burning of the infected dead branches, leaves and fruits) and the use of chemicals like Triadimenol, Captafol, Copper hydroxide, Dithianon, Copper oxychloride, Prochloraz 25\% EC 1ml/ 0.8-1.5 litres, Chlorothalonil 75\% WP $1 \mathrm{ml}$ per 0.6-0.8 litre [54], [3]. The use of complete or partial resistant varieties to anthracnose has also been recommended [55]. Cashew powdery mildew can be managed culturally by pruning and clearing the 
diseased branches and leaves [56], [57] and also by chemical methods such as the use of water-based organic fungicides (Penconazole, Triadimenol and Hexaconazole at the rate of $10-15 \mathrm{ml} /$ litre/tree at an interval of 21 days), wettable and dusts sulphur powder at the rate of $250 \mathrm{gm}$ per tree at 14 interval days has also been used [30], [58]. The cashew Pestalotia leaf spot has also been chemically controlled using Chlorothalonil 75\% WP (1 g/0.8-1 litre), Propamocarb 72.29\% (1 g/0.8-1 litre) and Metalaxl Mancozeb 58\% WP (1 g/ 0.8-1 litre) [3]. Cashew dieback can be managed culturally by clearing and burning of the diseased leaves on the whole cashew plant [59] or biologically by the use of Oecophylla smaragdina (weaver ant) for the control of suck feeding insects [58] or by the use of chemicals like Dimethoate $40 \%$ EC $1 \mathrm{ml} / 1-1.5$ litre, Lambda cyhaothrin EC $5 \mathrm{ml} / \mathrm{litre}$, Trichlorfos $90 \%$ crystal $1 \mathrm{~g} / 1$ litre and Betacypermethrin 4.5\% EC $1 \mathrm{ml} / 2.5-3$ litres [3].

During the survey, besides pathogens found to cause diseases on the cashew trees, insect pests were also observed in the various cashew orchards in the study areas. They were found to play a major role directly or indirectly in limiting cashew nut tree yield. The insects identified and documented during the survey in the various orchards included Oecophylla smaragdina (weaver ant), Anoplocne miscurvipeson, Pseudotheraptus devastans, Pachnoda cordata, Pachnoda marginata, Helopeltis bug, Helopeltis schoutedeni, mealybugs (Planococcus sp.), leaf and blossom webber Lamida moncusalis, termites (Odontotermes sp.), leaf miner, cashew girdler beetle (Analeptes trifasciata) and aphids (Aphis spp.). This calls for a major concern for cashew producers in the study areas and Ghana as a whole. Some of the collected insect species could not be identified and this calls for further studies in that regard. Insect pests' species, including leaf-chewing caterpillars, aphids, sap-sucking bugs, mites, scales and beetles constitute a major constraint to cashew production, resulting in leaves and fruit damage with subsequent death of the floral-flushing shoots and early abortion of immature fruits and nuts with corresponding yield losses [60].

In surveys conducted to identify the insect fauna and their distribution on cashew in major cashew growing communities in ten districts of Brong Ahafo, Northern, Eastern and Upper West regions of Ghana, [27] recorded a total of 170 insect species, some of which were identified to both family and generic levels. Some major insects such Apate telebrans, Anoplocne miscurvipeson, Pseudotheraptus devastans, Pachnoda cordata, Helopeltis schoutedeni, Analeptes trifasciata, Homoeocerus pallens, Clavigralla shadabi, Clavigralla tomentosicollis, Piezodorus rubrofasciatus, Nezara viridula, Diplognatha gagates etc. have also been reported in that study and in line with this study, insect pests such as Anoplocne miscurvipeson, Pseudotheraptus devastans, Pachnoda cordata and Helopeltis schoutedeni were found to be associated with various cashew orchards in the study areas. [27] also reported Analeptes trifasciata - a branch girdler beetle as the most common and destructive beetle, this observation has also been recorded in this study, where the beetle was found to girdle round several cashew branches in most of the communities with subsequent tipping-off of the girdled branches. In other parts of the world, Nair [1] reported more than 190 insects and mite species on cashew nut trees in major cashew growing regions, with Helopeltis antonii (mosquito bug) being one of the most prevalent together with root and stem borers [1]. In agreement with the results of the present study, it was also found that mosquito bugs were the most prevalent among all the insects identified in the orchards.

In Guinea-Bissau, a study on new records of insect pest species associated with cashew, [61], reported Plocaederus ferrugineus, Apate terebrans and weaver ants as major pests of concern to cashew production. Their findings on the weaver ant as one of the major insect species affecting cashew production has been corroborated by this study. Other insect pests recorded in some regions of Guinea-Bissau included Pseudotheraptus sp., Pseudococcus longispinus, Selenothrips rubrocinctus, Analeptes trifasciata Fabricius, Helopeltis sp. and Mecocorynus loripes Chevrolat, stem girdler- A. trifasciata among others [32], [33]. Both Helopeltis sp. and A. trifasciata are considered the most common and destructive insect pests in a number of West African countries [32], [27], [62]. The increased incidence of pests and diseases associated with cashew orchards in the study areas is a matter of concern not only to the cashew farmers whose economic livelihood largely depends on this newly discovered golden cash crop of the 21 st century, but also Ghana as a whole.

\section{CONCLUSION}

This study provided a rich profile of cashew insect pests and diseases of economic importance that will open a window for further research in cashew production and add to the existing knowledge of literature. The study documented major pathogens (fungi, algae, and lichen) of cashew to include Colletotrichum gloeosporioides species complex, Lasiodiplodia theobromae, Curvularia lunata. Penicillium sp., Cephaleuros sp. (red rust), Pestalotia sp., powdery mildew, mushroom, and lichens. These fungi and algae have been associated with diseases like anthracnose, gummosis, die-back, Pestalotia and algae leaf spots and branch pruning rot. Anthracnose, gummosis, algal leaf, and stem spots (red rust) and cashew kernel infection by Curvularia lunata constituted the major diseases in the study areas. The insect species recorded include Pseudotheraptus devastans, Helopeltis bug, Helopeltis schoutedeni, Oecophylla smaragdina (weaver ant), Pachnoda marginata, Pachnoda cordata, Termites (Odontotermes sp.), leaf and blossom webber Lamida moncusalis, aphids (Aphis spp.), cashew girdler beetle (Analeptes trifasciata), leaf miner, mealybugs (Planococcus sp.) and Anoplocne miscurvipeson. The sharp rise in the occurrence of insect pests and diseases in the number of cashew orchards in the visited communities calls for early intervention measures to mitigate or combat the situation and increase cashew productivity and yield output.

\section{ACKNOWLEDGMENT}

The authors wish to acknowledge the enormous support provided by the Department of Chemical Science of the University of Energy and Natural Resources for giving us their laboratory space to carry out this work. Our gratitude 
also goes to Mr. Thomas Kwame Fosu for his assistance in sample preparation during the laboratory work.

\section{REFERENCES}

[1] Nair, K. P. The agronomy and economy of important tree crops of the developing world. Access Online via Elsevier, 2010.

[2] Salam, M.A., Peter, K.V. Cashew - A Monograph. New Delhi: Studium Press (India) Pvt. Ltd. pp 257, 2010.

[3] Zhongrun, Z., Masawe, P.A.L. Diseases and Insect Pests of cashew in Tanzania. Tropical Crops Genetic Resources Institute-CATAS, China and Naliendele Agricultural Research Institute P. O. Box 509, Mtwara, Tanzania, 2014.

[4] Ohler, J.G. Cashew. Department of Agricultural Research, Koninklijk Instituut voor de Tropen Otuonye AH, Agbeniyi SO, Otuonye TC, Muyiwa AA (2014). Isolation and identification of fungi associated with cashew (Anacardium occidentale L.) leaf spot disease. Compr. Res. J. Agric. Sci, 2:34-39, 1979.

[5] Dedzoe, C.D., Senayah, J.K., Asiamah, R.D. Suitable agro-ecologies for cashew (Anacardium occidentale L.) production in Ghana. West Afr J Appl Ecol, 2(1) ISSN: 0855-4307, 2001.

[6] Bezerra, M.A., Lacerda, C.F.D., Gomes, F.E., Abreu, C.E.D., Prisco, J.T. Physiology of cashew plants grown under adverse conditions. Braz J Plant Physiol, 19: 449-461. doi:10.1590/S1677$04202007000400012,2007$.

[7] Khatoon, A., Ashirbad, M., Kunja, B.S. Major diseases of cashew (Anacardium Occidentale L.) Caused by fungi and their control in Odisha, India. Int. J. Biosci, pp. 68-74, 2017.

[8] Muntala, A., Norshie, P.M., Santo, K.G., Saba, C.K.S. Colletotrichum gloeosporioides Species Complex: Pathogen Causing Anthracnose, Gummosis and Die-Back Diseases of Cashew (Anacardium Occidentale L.) in Ghana. Euro J. of Agric and Food Sci, 2. https://doi.org/10.24018/ejfood.2020.2.6.146, 2020.

[9] Nari. Diseases and Insect pests of cashew. Technical report, Naliendele, Tanzania, pp. 62, 2009.

[10] Ghini, R., Bettiol, W., Hamada, E. Diseases in tropical and plantation crops as affected by climate changes: current knowledge and perspectives. Plant Pathol, 60:122-132. doi: 10.1111/j.13653059.2010.02403.x, 2011.

[11] Cardoso, J.E., Viana, J.M.P., Freire, F.C.O., Martins, M.V.V. "Doenças do cajueiro," in Agronegócio Caju-Práticas e Inovações, ed. J.P.P. Araújo (Brasília: Embrapa), 217-238, 2013.

[12] Shomari, S.H. A review of cashew research in Tanzania. Paper presented at the Tanzanian Agricultural Research Masterplan Conference, Arusha. 12-15 December, 1988.

[13] Sijaona, M.E.R., Reeder, R.H., Waller, J.M. Cashew leaf and nut blight. A new disease of cashew (Anacardium occidentale L.) in Tanzania caused by Cryptosporiopsis sp. http://www.bsapp.org.uk/ndr/jan2006/2005-75.asp, 2006.

[14] Dominic, M., Makobe, M., Agboton, B., Shomari, S., Tiedemann, A. Biology and infection mechanisms of Cryptosporiopsis spp. fungus causing blight disease on cashew (Anacardium Occidentale L.). J. Plant Sci, 2: 266-275, 2014

[15] Tibuhwa, D.D., Shomari, S.H. Pathogen causing cashew wilting diseases in Magawa village, Mkuranga, Coast region, Tanzania. Consultancy report regarding Macro-fungi associated with cashew wilt disease in Southern regions in Tanzania. pp. 24, 2012.

[16] Menezes, M. Doencas do Cajueiro (Diseases of Cashew). In: - Kimati H, Amorim L, Bergamin FA, Camargo LEA, Rezende JAAM (Eds.), Manual de Fitopatologia (Plant Pathology Manual). Editora Agronomica Ceres Ltda, S ao Paulo, pp 201-206, 1997.

[17] Wonni, I., Sereme, D., Ouedraogo, I., Kassankagno, A.I., Dao, I., et al. Diseases of Cashew Nut Plants (Anacardium occidentale L.) in Burkina Faso. Adv Plants Agric Res, 6(3), pp 216. DOI: 10.15406/apar.2017.06.00216, 2017.

[18] Afouda, L.C.A., Zinsou, V., Balogoun, R.K., Onzo, A., Ahohuendo, B.C. Inventaire des agents pathogènes de l'anacardier (Anacardium occidentale L.) au Bénin. Bulletin de la Recherche Agronomique du Bénin, 70:1840-7099, 2013.

[19] Freire, F.C.O., Cardoso, J.E., dos Santos, A.A., Viana, F.M.P. Diseases of cashew nut plants (Anacardium occidentale L.) in Brazil. Crop Prot, 21:489-494. doi: 10.1016/S0261- 2194 (01)00138-7, 2002.

[20] Freire, F.C.O. Angular leaf spot of cashew (Anacardium occidentale L.) caused by Septoria anacardii sp. nov. Agrotropica. 9:19-22, 1997.

[21] Batista, A.C., Bezerra, J.L., Castrillon, A.L., Matta, E.A.F. Novos ascomycetos folilicolas e caulinares (New ascomycetes from leaves and stems). Instituto de Micologia, Publicac-ao 431, Recife- PE, Brazil, pp 22, 1964.
[22] Urben, A.F., Mattos, J.K.A. Fungos folıcolas em cajueiro (Anacardium occidentale L.) no DF (Leaf fungi of cashew, Anacardium occidentale L., in the Federal District). Cerrado 6: 20-23, 1974.

[23] Ponte, J.J. Doencas do cajueiro no Nordeste brasileiro (Cashew Diseases in the Northeast of Brazil). Embrapa/DDT Documentos 10, Brasılia-DF, Brazil, pp 51, 1984.

[24] Teixeira, L.M.S. Doencas (Diseases). In: Lima, V.P.M.S. (Ed.), - A cultura do Cajueiro no Nordeste do Brasil (The Cashew Crop in the Brazilian Northeastern). BNB/ETENE, Estudos Socioeconomicos 35 , Fortaleza-CE, Brazil, 231-266, 1988.

[25] Malipatil, M., Houston, W. Bioecology of cashew insects at Wildman River, NT. Working Papers of the Third Annual Cashew Research and Development Workshop, February 21, 1990, Darwin, Northern Territory, 22-25, 1990.

[26] Xianli, P., Van Der Geest, L.P.S. Insect pests of cashew in Hainan, China, and their control. J. Appl. Entomol, 110: 370-377, 1990.

[27] Dwomoh, E.A., Ackonor, J.B., Afun, J.V.K. Survey of insect species associated with cashew (Anacardium occidentale Linn.) and their distribution in Ghana. Afr. J. Agric. Res, 3: 205-214, 2008

[28] Boma, F., Topper, C.P., Stathers, T. Population dynamics of Helopeltis spp. on cashew in southern Tanzania, Proceedings of the International Cashew and Coconut Conference, Dar es Salaam, Tanzania. 17-22 February 1997, 185-189, 1997.

[29] Martin, D.J., Topper, C.P., Bashiru, R.A., Boma, F., de Waal, D. Harries, H.C., Kasuga, L.J., Katilila, N., et al. Cashew nut production in Tanzania: constraints and process through Integrated Crop Management. Crop Prot, 15:5-14, 1997.

[30] Topper, C.P., Grunshew, J., Pearce, M., Boma, F., Stathers, T., Anthony, J. Preliminary observations on Helopeltis and Pseudotheraptus damage to cashew leaves and panicles., Proceedings of the International Cashew and Coconut Conference, Dar es Salaam, Tanzania, 17-22 February 1997, 182-183, 1997.

[31] Maruthadurai, R., Desai, A.R., Prabhu, H.R.C., Singh, N.P. Insect Pests of Cashew and their Management. Technical Bulletin No. 28, ICAR Research Complex for Goa, Old Goa, 2012

[32] Topper, C.P., Caligari, P.D.S., Camara, M., Diaora, S., Djaha, A. Coulibaly, F., Asante, A.K., Boamah, A., Ayodele, E.A., Adebola, P.O. West Africa regional cashew survey (covering the countries Guinea, Guinea Bissau, Côte d'Ivoire, Ghana and Nigeria). Volume 1. Report number BHA 01109. BioHybrids Agrisystems Ltd, Woodley, U.K, 2001.

[33] Mendes, L.F., Catarino, L., Bívar, D.S.A. Xilófagos do cajueiro (Anacardium occidentale), em especial na Guiné-Bissau. Boletim da Sociedade Portuguesa de Entomologia. 12: 201-212, 2012.

[34] Cardoso, J.E., Santos, A.A., Rossetti, A.G. et al. Relationship between incidence and severity of cashew gummosis in semiarid north-eastern Brazil. Plant Pathol, 53: 363-367, 2004.

[35] Cysne, A.Q., Cardoso, J.E., Maia, A.H.N. et al. Spatialtemporal analysis of gummosis in three cashew clones at Northeastern Brazil. J. Phytopathol, 158: 676-682, 2010.

[36] Pandey, A., Yadava, L.P., Manoharan, M., Chauhan, U.K., Pandey, B.K. Effectiveness of cultural parameters on the Growth and sporulation of Colletotrichum gloeosporioides causing anthracnose disease of Mango (Mangifera indica L.) OnLine J. Biol Sc, 12:123133,2012

[37] Gautam, A.K., Avasthi, A., Bhadauria, R. First report of anthracnose caused by Colletotrichum gloeosporioides on Boehravia diffusa in India. Arch Phytopathol, Pl Protect, 45: 2502-2506, 2012

[38] Freire, F.C.O., Cardoso, J.E. "Doenças do cajueiro," in Doenças De Fruteiras Tropicais De Interesse Agroindustrial, eds F.C.O. Freire, J.E. Cardoso, and F.M.P. Viana (Brasília: 420 Embrapa, Informação Técnica), 192-225, 2003.

[39] Figueiredo, L.C., Figueirêdo, G.S., Quecine, M.C., Cavalcanti, F.C.N., Santos, A.C., Costa, A.F. et al. Genetic and pathogenic diversity of Colletotrichum gloeosporioides, the causal agent of cashew anthracnose. Indian J. Fundam. Appl. Life Sci, 2:250-259, 2012.

[40] Lopez, A.M.Q., Lucas, J.A., Colletotrichum isolates related to anthracnose of cashew trees in Brazil: morphological and molecular description using LSU rDNA sequences. Braz. Arch. Biol. Technol 53 741-752. doi: 10.1590/S1516-89132010000400001, 2010.

[41] Otuonye, A. H., Agbeniyi, S. O., Otuonye, T. C., and Muyiwa, A. A Isolation and identification of fungi associated with cashew (Anacardium Occidentale L.) leaf spot disease. Compr. Res. J. Agric. Sci., 2:34-39, 2014.

[42] Roossinck, M.J., Martin, D.P., Roumagnac, P. Plant virus metagenomics: Advances in virus discovery. Phytopathology. 105: 716-727, 2015.

[43] Intini, M. Phytopathological aspects of cashew (Anacardium occidentale L.) in Tanzania. Int J Trop Dis, 5: 115-130, 1987. 
[44] Sijaona, M.E.R., Reeder, R.H., Waller, J.M. Cashew leaf and nut blight- A new disease of cashew in Tanzania caused by Cryptosporiopsis spp. http:www.bspp.org.uk/ndr/jan2006/200575.asp, 2005

[45] Tibuhwa, D.D., Shomari, S.H. Fusarium Wilt Disease: An Emerging Threat to Cashew Nut Crop Production in Tanzania. Asian J of Plant Pathol, 10:36-48, 2016.

[46] Araújo, J.P.P. Agronegócio Caju: Práticas e inovações. Brasília: Embrapa. pp 532, 2013.

[47] Uaciquete, A., Korsten, L., Van der Waals, J.E. Epidemiology of cashew anthracnose (Colletotrichum gloeosporioides Penz.) in Mozambique. Crop Prot, 49: 66-72, 2013.

[48] Adeniyi, D.O., Orisajo, S.B., Fademi, O.A., Adenuga, O.O., Dongo, L.N. Physiological studies of fungi complexes associated with cashew diseases. J. Agric. Biol. Sci, 6: 34-38, 2011.

[49] Monteiro, F., Romeiras, M.M., Figueiredo, A., Sebastiana, M., Baldé, A., Catarino, L., Batista, D. Tracking cashew economically important diseases in the West African region using metagenomics. Front. Plant Sci, 6: pp. 482. doi: 10.3389/fpls.2015.00482, 2015.

[50] Nambiar, K.K.N. Controlling cashew diseases. Indian Farming, 28:1718,1978 .

[51] Ponte, J.J., Nobre, R.H.P., Nascimento, M.L.R. Bolor verde (Penicillium digitatum Sacc.) uma incidencia nociva a am amendoa do cajueiro (Green mold (Penicillium digitatum Sacc.) a dangerous rot of cashew kernel). Rev. Soc. Bras. Fitopatologia, 6:44-46, 1975.

[52] Andrade, J.S., Maia, G.A., Holanda, L.F.F., Sales, M., Figueredo, R.W Influencia do teor de umidade na estabilidade de amendoas de castanha de caju (Anacardium occidentale L.) (Influence of humidity content on the stability of cashew kernels (Anacardium occidentale L.). Rev. Bras. Fruticultura. 2: 23-33, 1990.

[53] Esuruoso, O.F. Fungi associated with kernel rot disease of cashew (Anacardium occidentale L.) in Nigeria. Int. Biodeterior, Bull 10: $57-$ 59, 1974.

[54] Sijaona, M.E.R. Important diseases and insect pests of cashew in Tanzania. Naliendele Agricultural Research Institute, Tanzania, 2013.

[55] Masawe, P.A.L. Tanzanian Cashew Cultivars Selected Clones. Cashew Research Programme, Naliendele Agricultural Research Institute, P. O. Box 509, Mtwara, Tanzania, 2006.

[56] Casulli, F. Prove de lotte chimica sull' anacardio (Anacardium occidentale L.) in Tanzania. Rivista di Agricoltura Subtropicale e Tropicale. 75: 259-266, 1981.

[57] Shomari, S.H. Studies on the biology and epidemiology of Oidium anacardii Noack. The powdery mildew pathogen of cashew. $\mathrm{PhD}$ Thesis, University of Birmingham, 1996.

[58] Sijaona, M.E.R., Shija, B., Anthony, J.K. Fungicide screening for the control of powdery mildew on cashew in Tanzania. A paper submitted to registrar of pesticides TPRI, P.O. box 3024, Arusha, Tanzania, 2001.

[59] Intini, M., Sijaona, M.E.R. Little known disease of cashew (Anacardium occidentale L.) in Tanzania. Rivista di Agricoltura Subtropicale e Tropicale. 77:421-29, 1983.

[60] Azam-Ali, S.H., Judge, E.C. Small-scale cashew nut processing. Rugby, UK: Food and Agriculture organization - FAO. http:// www.anacardium.info/IMG/pdf/Small- scale_Cashew Nut ProcessingFAO_2001.pdf. Accessed 13 November 2020, 2001.

[61] Vasconcelos, S., Mendes, L.F., Beja, P., Hodgson, C.J., Catarino, L. "New Records of Insect Pest Species Associated with Cashew, Anacardium occidentale L. (Anacardiaceae), in Guinea Bissau," African Entomology. 22: 673-677. (13, July, 2020). https://doi.org/10.4001/003.022.0324, 2014.

[62] Asogwa, E.U., Ndubuaku, T.C.N., Hassan, A.T. Distribution and damage characteristics of Analeptes trifasciata Fabricius (Coleoptera: Cerambycidae) on cashew (Anacardium occidentale Linnaeus) in Nigeria. Agr Biol J N Am, 2: 421-443, 2011.

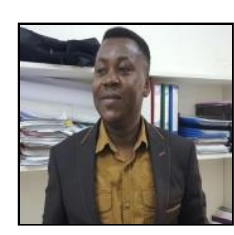

Dr. A. Muntala is a Lecturer at the Department of Horticulture and Crop Production of the University of Energy and Natural Resources, Sunyani in the Bono Region of Ghana. His area of specialization is Plant Protection. He is currently the coordinator for projects and student's thesis of the abovementioned Department. He is a member of America Phytopathology Society (APS) and Ghana Science Association (GSA). He has number of publications in international peer review Journals. 